\title{
Effect of Garlic on Growth Performance, Nutrient Utilization and Survival of an Ecotype Cichlid, 'Wesafu'
}

\author{
Megbowon, $\mathrm{I}^{1}$., Adejonwo, O.A ${ }^{2}$., Adeyemi, Y.B ${ }^{3}$. Kolade O.Y ${ }^{4}$, \\ Adetoye, A.A.A ${ }^{5}$, C.A. Edah $^{6}, \mathrm{~B}$, Okunade, O. $\mathrm{A}^{7}$ and Adedeji, A.K ${ }^{8}$ \\ Nigerian Institute for Oceanography and Marine Research, Victoria Island, Lagos
}

\begin{abstract}
Garlic (Allium sativum) is probably one of the earliest known medicinal plants and has been used to improve growth and resistance of a number of livestock and fish. This study was conducted to show the effects garlic on the growth performance and nutrient utilization of fingerlings of an ecotype cichlid commonly called 'wesafu' in Nigeria. A total of 600 fingerlings $(1.4 \pm 0.12 \mathrm{~g})$ were obtained from the hatchery of the Nigerian Institute for Oceanography and Marine Research, Victoria Island, Lagos and used for the study. They were randomly assigned to 12 plastic tanks each, $0.5 \mathrm{~m}^{3}$ with a flow-through water system. Five doses of garlic, 0 (control), $10 \mathrm{~g}, 20 \mathrm{~g}$ and $30 \mathrm{~g}$ of fresh clove of garlic were mixed with $1 \mathrm{~kg}$ feed. The control diet was free from garlic. The experiment extended lasted for 12 weeks. The results showed significantly increased weight and growth performance of the ecotype cichlid $(P<0.01)$ in all groups fed on garlic. The mortalities were lower in diet supplemented with garlic than in the control group. The improve survival rate may be due to the enhanced immune response resulting from improved defense mechanism.
\end{abstract}

Key Words: Garlic, Growth, Nutrient utilization, Survival, 'wesafu'

\section{Introduction}

There has been a growing concern on the use of antimicrobial agent in Aquaculture, as these substances increase the selective pressure they exert on the microbes and brings about the emergence of resistant bacteria. This is achieved by transferring resistant genes to bacteria which are not exposed to antibiotics. Hormones, antibiotics and many other chemical substances have been tested as growth promoters, antibacterial agent and for other purposes in aquatic animals (Jayaprakas and Sambhu, 1996; Masahiro, 1999), but their use in aquaculture production cannot be recommended because of the residual effects in the muscle of fish as well as prawns.

Plants are natural sources of safer and cheaper chemicals. Plant products have been reported to promote various activities like anti-stress, growth enhancement, appetite stimulation and immune-stimulation in aquaculture practices (Citarasu et al., 2001, 2002; Sivaram et al., 2004). Furthermore, the antimicrobials normally lead to drug residues in the fish in addition to having negative impact on the environment (FAO/WHO/OIE, 2006). It has also been reported that antimicrobial agents can generate cross-resistance against human antimicrobials, which has the potential of health harzard on man (Witte et al., 1999).

Garlic (Allium sativam) has been proven to control pathogens, particularly bacteria and fungi, thus improving the health of fish (Corzo-Martinez et al., 2007). It has been used in ancient Egypt in treating many ailments such as heart diseases, headache, bites worms and tumors (Salah et al., 2008). Garlic has many beneficial effects on livestock and man. These include exhibiting antimicrobial, antioxidant, anti-hypertensive properties (Sivam, 2001). Previous work suggested that these functions are attributable to the bioactive components of the plant, garlic which include allin and allicin. Allicin is the most abundant compound representing almost 70\%of all thiosulfinates present (Han et al., 1995). : In Nigeria there exist an ecotype cichlid, called 'wesafu' in Epe lagoon, Lagos state where it is highly priced and grows to a size of over 1,500g in the wild (Bombatta et al,2005). At present $1 \mathrm{~kg}$ of wesafu is sold for N1,200 and N1,500 in Epe,Lagos (Megbowon and Bombatta,2009). The present study was conducted to evaluate the efficiency of the garlic (Allium sativum L) in improving growth performance and survival in this cichlid fish

1. Fish

\section{Materials And Methods}

A total of 600 fry (mean individual initial weight $=1.4 \pm 0.12 \mathrm{~g}$ ) of the ecotype cichlid 'wesafu' were divided into four equal treatments. Each treatment and the control consisted of three equal replicates ( 50 fish per replicate) that were randomly assigned to 20 plastic tanks $0.5 \mathrm{~m}^{3}$ each. Fish were fed on a base diet of $35 \%$ crude protein at $3 \%$ body weight per day, divided into two feeding times. 


\section{Garlic and diet}

Garlic (Allium sativum $\mathrm{L}$ ) was procured from the local market in Lagos Island, Lagos, Nigeria, crushed and five doses, A (0\%), B (10\%), C (20\%) and D (3\%) of garlic $\mathrm{kg}^{-1}$ feed were produced. A balanced ration was prepared (Table 1). The ingredients were obtained from specialized suppliers and prepared locally in the Fish Technology department of Nigerian Institute for Oceanography and Marine Research, Lagos in the form of pellets. The basal diet was prepared by grinding the feed ingredients to meal, mixed and pelletized using locally fabricated pelletizing machine after Oil (vegetable) was added gradually to assure the homogeneity of the ingredients. The pellets were prepared biweekly, air-dried at room temperature for 24 hours and stored in a refrigerator $\left(4^{\circ} \mathrm{C}\right)$.

\section{Experimental design}

The study was conducted over a period of twelve weeks to evaluate the efficiency of garlic in promoting growth and survival of the cichlid. 'Wesafu' fry were divided into four equal groups A $0 \mathrm{~g}$ garlic $/ \mathrm{kg}$ feed), B ( $10 \mathrm{~g}$ garlic $/ \mathrm{kg}$ feed), C (20g garlic/ $\mathrm{kg}$ feed), D (30g garlic/ $\mathrm{kg}$ feed). Three replicates were used in each group and were randomly assigned to 12 plastic tanks each, $0.5 \mathrm{~m}^{3}$. Treatment $\mathrm{A}(0 \mathrm{~g}$ garlic $/ \mathrm{kg}$ feed) served as the control.

Table 1: Composition of the basal die used for the study

\begin{tabular}{|l|l|l|l|}
\hline \multirow{2}{*}{ Ingredients } & Diet (\%) & Protein (\%) \\
\cline { 3 - 4 } & & Ingredient & Feed \\
\hline Fish meal & 8.2 & 72 & 5.77 \\
\hline $\begin{array}{l}\text { Soybean } \\
\text { meal }\end{array}$ & 53.1 & 47 & 25.43 \\
\hline Wheat flour & 5.3 & 13.2 & .67 \\
\hline $\begin{array}{l}\text { Ground } \\
\text { corn }\end{array}$ & 29.2 & 11.0 & 3.18 \\
\hline $\begin{array}{l}\text { Vitamin } \\
\text { mix }\end{array}$ & 0.05 & 0.00 & 0.00 \\
\hline $\begin{array}{l}\text { Mineral mix } \\
\begin{array}{l}\text { Vegetable } \\
\text { oil }\end{array}\end{array}$ & 0.07 & 0.00 & 0.00 \\
\hline NaCl & 2.00 & 0.00 & 0.00 \\
\hline Total & 99.92 & 0.00 & 0.00 \\
\hline
\end{tabular}

\section{GROWTH PERFORMANCE}

Mean weight gain, Specific growth rate (SGR), food conversion rate (FCR), and survival were calculated as follows:
1. Weight gain $=\mathrm{W}_{1}-\mathrm{W}_{0}$
2. Specific growth rate $(\mathrm{SGR})=\left(\ln \mathrm{W}_{1-} \ln \mathrm{W}_{0} / \mathrm{T}\right) \mathrm{X} 100$
3. Average daily Growth rate $=$ Weight gain $/ \mathrm{T}$ )
4. Food conversion rate $=$ Feed intake $(\mathrm{g}) /$ Weight gain $(\mathrm{g})$
5. Protein Efficiency Ratio (PER) $=$ Weight gain/protein intake
6. Survival $(\%)=$ Number of experimental fish at the end of experiment
Number of experimental fish at the beginning of experiment

Where:

$\mathrm{W}_{0}=$ Mean initial weight $(\mathrm{g})$

$\mathrm{W}_{1}=$ Mean final weight $(\mathrm{g})$

$\mathrm{T}=$ Experimental period (days)

\section{STASTICAL ANALYSIS}

Growth and survival rates were compared using one-way analysis of variance (ANOVA) and Fisher's LSD to determine significant differences between means. Because mean initial weights differed significantly among the genetic groups studied, the specific growth rate (SGR) of the fish were compared using Analysis of covariance with the initial weight serving as covariate. 
III. Results

Table 1. Growth performance and nutrient utilization of the ecotype cichlid, 'wesafu' reared in plastic tanks

\begin{tabular}{|c|c|c|c|c|}
\hline \multirow[t]{2}{*}{ Items } & \multicolumn{4}{|c|}{ Garlic level (g/kg feed) } \\
\hline & $\mathrm{A}(0 \%)$ & $\mathrm{B}(10 \%)$ & $\mathrm{C}(20 \%)$ & $\mathrm{D}(30 \%)$ \\
\hline Initial weight (g) & $1.39 \pm 0.012 \mathrm{a}$ & $1.39 \pm 0.011 \mathrm{a}$ & $1.39 \pm 0.011 \mathrm{a}$ & $1.39 \pm 0.043 \mathrm{a}$ \\
\hline Final weight (g) & $8.03 \pm 0.057 \mathrm{c}$ & $8.17 \pm 0.87 \mathrm{a}$ & $9.03 \pm 0.211 \mathrm{a}$ & $9.22 \pm 0.13 \mathrm{a}$ \\
\hline Weight gain (g) & $6.64 \pm 0.047 \mathrm{c}$ & $6.78 \pm 0.034$ & $7.64 \pm 0.065$ & $7.83 \pm 0.012$ \\
\hline $\operatorname{SGR}(\% /$ day $)$ & $1.84 \pm 0.035 \mathrm{c}$ & $1.86 \pm 0.022 \mathrm{ab}$ & $1.96 \pm 0.012 \mathrm{a}$ & $1.97 \pm 0.031 \mathrm{a}$ \\
\hline Survival rate $(\%)$ & $91.6 \pm 2.3 b$ & $93.6 \pm 2.52 \mathrm{a}$ & $94.3 \pm 2.91 \mathrm{a}$ & $95.4 \pm 5.33 \mathrm{a}$ \\
\hline Feed Intake (g) & $11.21 \pm 0.54 \mathrm{a}$ & $11,21 \pm 0.61 \mathrm{a}$ & $11.27 \pm 0.55 \mathrm{a}$ & $11.35 \pm 0.37 \mathrm{c}$ \\
\hline FCR & $1.68 \pm 0.11 \mathrm{a}$ & $1.65 \pm 0.13 \mathrm{a}$ & $1.63 \pm 0.16 \mathrm{a}$ & $1.63 \pm 0.15 \mathrm{c}$ \\
\hline PER & $1.97 \pm 0.012$ & $1.96 \pm 0.014$ & $1.99 \pm 0.013$ & $1.99 \pm 0.013$ \\
\hline
\end{tabular}

Mean \pm S.E having the same letter in the same row are not significantly different at $P<0.05$

Table 1 showed that fish supplemented with garlic B, C and D performed better than the control $0 \mathrm{~g} / \mathrm{kg}$ feed) in terms of growth performance and nutrient utilization. The survival rate was least in the control compared to the three other treatments. The survival was significantly greater in $\mathrm{B}, \mathrm{C}$ and $\mathrm{D}$ where they were supplemented with garlic. In the present study there was slight variation but not statistically significant $(\alpha=0.05)$, in the survival among the various treatments.

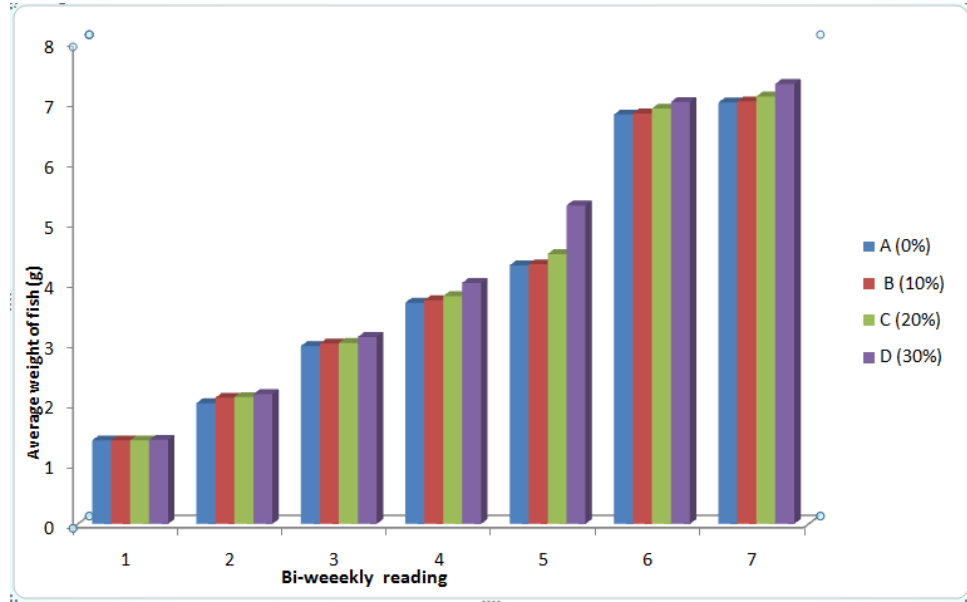

Fig. 1: Bi-weekly growth of 'wesafu' fed varying levels of garlic

Table 1 showed progressive increase in weight of the three treatments and control. The finding showed the weekly growth in A (control) was lower throughout the experimental period than for B, C and D.

\section{Discussion}

Garlic has found its usage as food by man as well as livestock for centuries. They are often used for the cure of a number of animal diseases (Shalaby et al., 2006). . Several herbs such as garlic, onion among others have been tested and evaluated for promoting growth promoting (Citarasu et al., 2002; Sivaram et al., 2004), feed conversion ratio (Shalaby et al., 2003, enhancement of protein digestibility (El-Dakar et al., 2004) in fishes and other aquatic organisms. Khalil et al, (2001) reported that garlic contains allicin, which improves the performance of intestinal flora, thus improving digestion. This consequently enhances the utilization of energy, bringing about improved growth.

In the present study, fish feed containing garlic had significantly better growth and feed utilization as compared to fish fed the control diet with $0 \%$ garlic. This proved that dietary supplementation of garlic enhanced the fish growth and survival. This is in agreement with Shalaby et al. (2006) who reported significant increased weight gain, feed efficiency, protein efficiency ratio (PER) and specific growth rate (SGR) in the Nile tilapia (Oreochromis niloticus) when fed diet containing garlic powder of $30 \mathrm{~g} / \mathrm{kg}$ diet. Furthermore, Diab et al. (2002) reported that feeding diet with $2.5 \%$ garlic resulted $/ \mathrm{kg}$ diet in the highest growth performance in the Nile tilapia (O. niloticus). Abou-Zeid (2002) observed a positive improvement in biomass and specific growth rate with garlic supplementation. However, Metwally (2009) reported that the best performance in terms of growth was observed when Oreochromis niloticus was fed with diet containing $32 \mathrm{~g} / \mathrm{kg}$ diet of garlic powder. Although growth is enhanced with garlic supplementation, high dose of garlic in fish may reduce feed intake as a result of its unpleasant odour. Wanapat et al. (2008) found significantly higher digestibility, absorption and retention of $\mathrm{N}$ in garlic powder supplemented groups compared to control group without garlic. Although there is constant controversy concerning the effect of garlic as growth promoter for fish, the present results suggest that dietary garlic for juvenile of ecotype cichlid, 'wesafu' could positively affect growth and survival. Garlic have been 
reported to control pathogens, combat stress, increase the welfare of fish (Ress et al., 1993) and enhance the immune response (Corzo-Martinez et al., 2007) and consequently this will have a positive effect on the survival rate. The improve survival rate may be due to the enhanced immune response resulting from improved defense mechanism.

\section{Acknowledgement}

We wish to acknowledge Dr Oresegun K (Assistant Director, Biotechnology, NIOMR) for offering useful suggestions in the course of the work. I equally commend Messrs Adeniran Adebowale and Dada Akinkunmi, the project assistants, who assisted in feeding and cleaning the rearing facility.

\section{References}

[1]. Abou-Zeid S.M (2002). The effects of some medical plants in reproductive and productive performance of Nile tilapia fish. Cairo University, Faculty of Agriculture (PhD Thesis)

[2]. Citarasu, T., M. M. Babu, S. M. J. Punitha, K. Venket Ramalingam and M. P. Marian. 2001. Control of pathogenic bacteria using herbal biomedicinal products in the larviculture system of Penaeus monodon. International Conference on Advanced Technologies in Fisheries and Marine Sciences, MS University, India.

[3]. Citarasu, T., R. R. Sekar, M. M. Babu and M. P. Marian. 2002. Developing Artemia enriched herbal diet for producing quality larvae in Penaeus monodon. Asian. Fish. Sci. 15:21-32.

[4]. Corto-Martinez, M., Corzo, N. and Mar Villamiel. (2007). Biological properties of onions and garlic, Trends in food Sciences and Technology, 18; 609-625.

[5]. Diab, A.S, El-Nagar, G.O and Abd-El Hady (2002). Evaluation of Nigella sativa (black seed;Baraka), Allium sativum (garlic) and BIOGEN as feed additives on growth performance and immunostimulant of O.niloticus fingerlings, Suez Canal Vet. Med. Journ.745-775.

[6]. El-Dakar, A. Y., G. D. I. Hassanien, S. S. Gad and S. E. Sakr. 2004a. Use of medical and aromatic plants in fish diets: I. Effect of dried marjoram leaves on performance of hybrid tilapia Oreochromis niloticus $\square$ Oreochromis auraus, fingerlings. J. Egypt. Acad. Soc. Environ. Dev. (B. Aquacult.) 5:67-83.

[7]. FAO/WHO/OIE (2006). Expert consultation on antimicrobial use in aquaculture and antimicrobial resistance, Seoul, Republc of South Korea, June, 13-16.

[8]. Han, J.L., Lawson, G. Han and Han, P. (1995).Spectrophotometric method for quantitative determination of allincin and total garlic thiosolfinates. Analytical Biochemistry, 225; 157-160.

[9]. Jayaprakas, V. and C. Sambhu. 1996. Growth response of white prawn, Penaeus indicus to dietary L-carnitine. Asian. Fish. Sci. 9:209-219.

[10]. Khalil, R. H., B. M. Nadia and M. K. Soliman. 2001. Effects of Biogen and Levamisol Hcl on the immune response of cultured Oreochromis niloticus to Aeromonas hydrophila vaccine. Beni-Suef Vet. Med. J., Egypt, XI (2): 381-392.

[11]. Ress L. P., Minney S. F., Plummer N. J., Slatter J. H. \& Skyrme D. A. (1993). A quantitative assessment of the antimicrobial activity of garlic (Allium sativum). World Journal of Microbiology and Biotechnology, 9: $303 \quad-\quad 307$. http://dx.doi.org/10.1007/BF00383068

[12]. Masahiro Sakai. 1999. Current research status of fish immunostimulants. Aquaculture 172:63-92.

[13]. Metwally, M.A.A.(2009). Effect of garlic (Allium sativum) on some antioxidant activities in Tilapia nilotica (Oreochromis niloticus). World J. of Fish Mar. Sci. 1: 56-64.

[14]. Megbowon, I., Fashina-Bombata, H.A., Mojekwu, T.O. and Okuade O.A. (2009). Genetic Improvement of Tilapia: Challenges and Prospects in Nigeria. Nigerian Journal of Fisheries. Vol.6 (1\&2), 21-30.

[15]. Salah M.A, Nashwa, M.A.T and Mohamed, F.T (2008). Proceedings of $8^{\text {th }}$ International Symposium on Tilapia in Aquaculture, Ciro, Egypt, 12-14, October, 2008; 277-296.

[16]. Shalaby, A.M., Khattab, Y.M. and Abdel Rahman A.M.(2006). Effect of garlic (Allium sativum) and chloramphenicol on growth performance, physiological parameters and survival of Nile tilapia (Oreochromis niloticus). J. Veenom. Anim. Toxins, Incl. Trop. Dis.12: 172-201

[17]. Siva, G.P (2001). Recent advances on the nutritional benefits associated with the use of garlic as supplement. .American Society of Nutrition Science; 2(1), 1106-1108

[18]. Sivaram, V., M. M. Babu, T. Citarasu, G. Immanuel, S. Murugadass and M. P. Marian. 2004. Growth and immune response of juvenile greasy groupers (Epinephelus tauvina) fed with herbal antibacterial active principle supplemented diets against Vibrio harveyi infections. Aquaculture 237:9-20.

[19]. Witte, W., Klare, I, and Werner, G. (1999). Selective pressure by antibiotics as feed additives, Infection, 27 (Suppl. 2); 35 -38. 